\title{
Transmission Electron Microscopy for the Quantitative Analysis of Testis Ultra Structure
}

\author{
Saeed Shokri ${ }^{*}$, Masoud Hemadi² and Robert John Aitken ${ }^{3}$ \\ ${ }^{1}$ Anatomy Department, School of Medicine, \\ Zanjan University of Medical Sciences, Zanjan, \\ ${ }^{2}$ Fertility and Infertility Research Center, Imam Khomeini Hospital, Faculty of Medicine, \\ Ahvaz Jundishapur University of Medical Sciences, Ahvaz, \\ ${ }^{3} A R C$ Centre of Excellence in Biotechnology and Development, \\ Discipline of Biological Sciences, University of Newcastle, NSW, \\ 1,2Iran \\ ${ }^{3}$ Australia
}

\section{Introduction}

\subsection{Testes structure}

The testes have two functions: they produce the male gametes, spermatozoa, and also produce the male sexual hormone, testosterone, which stimulates the accessory male sexual organs and causes the development of the masculine extragenital sexual characteristics. The testis is surrounded by a thick capsule, the tunica albuginea, from which a conical mass of connective tissue, the mediastinum testis, projects into the testis [1]. The tunica albuginea is covered externally by a serosa. From the mediastinum, delicate fibrous septa radiate towards the tunica albuginea and divide the parenchyma of the testis into about 300 lobuli testis, which communicate peripherally. Each lobule contains 1-4 convoluted seminiferous tubules (about 150-300 $\mu \mathrm{m}$ in diameter, 30-80 $\mathrm{cm}$ long). Interstitial tissue between the convoluted tubules is continuous with a layer of loose vascular connective tissue, the tunica vasculosa testis, which is found beneath the tunica albuginea. Each seminiferous tubule continues near the mediastinum into a straight tubule, a tubules rectus. The straight tubules continue into the rete testis, a labyrinthine system of cavities in the mediastinum [1, 2].

\subsection{The convoluted seminiferous tubules}

These tubules are enclosed by a thick basal lamina and surrounded by 3-4 layers of smooth muscle cells (or myoid cells). The insides of the tubules are lined with seminiferous epithelium, which consists of two general types of cells: spermatogenic cells and Sertoli cells (fig 3, 5).

${ }^{*}$ Corresponding Author 

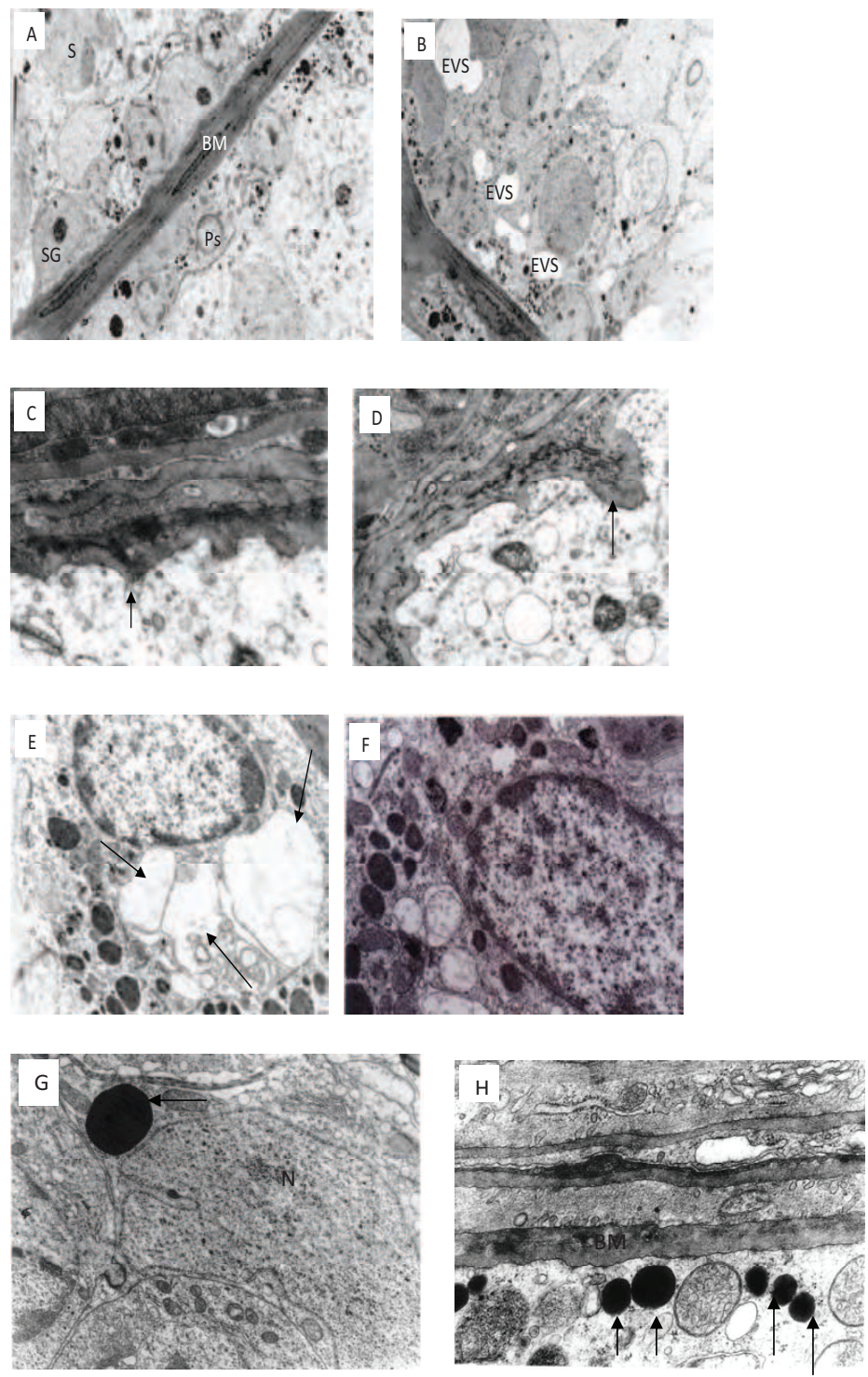

Fig. 1. Electron micrograph (TEM) of rat testes from: A, the control group showing normal basement membrane (BA), primary spermatocytes (PS), spermatogonia (SG) and Sertoli cell $(S)(\times 4000)$. B, the animals in experimental group showing empty vacuolar spaces (EVS) in the Sertoli and spermatocyte cells $(\times 5000)$. signs of inflammatory damage of testicular tissue in the form of irregular (C) and thickened (D) basal lamina $(\rightarrow)$ in $(\times 11000$ and $\times 13000)$, cytoplasmic vacuolation $(\rightarrow)$ in the Laydig $(E)$ cells in experimental group $(\times 12000)$ in comparision with normal Leydig cell $(\mathrm{F})$ in control group $(\times 15000)$, Lipid droplets $(\rightarrow)$ in Sertoli cells (N: Sertoli nucleus) in experimental group [G (×22000)] (BM: Basement Membrane) $[\mathrm{H}(\times 23000)]$. 

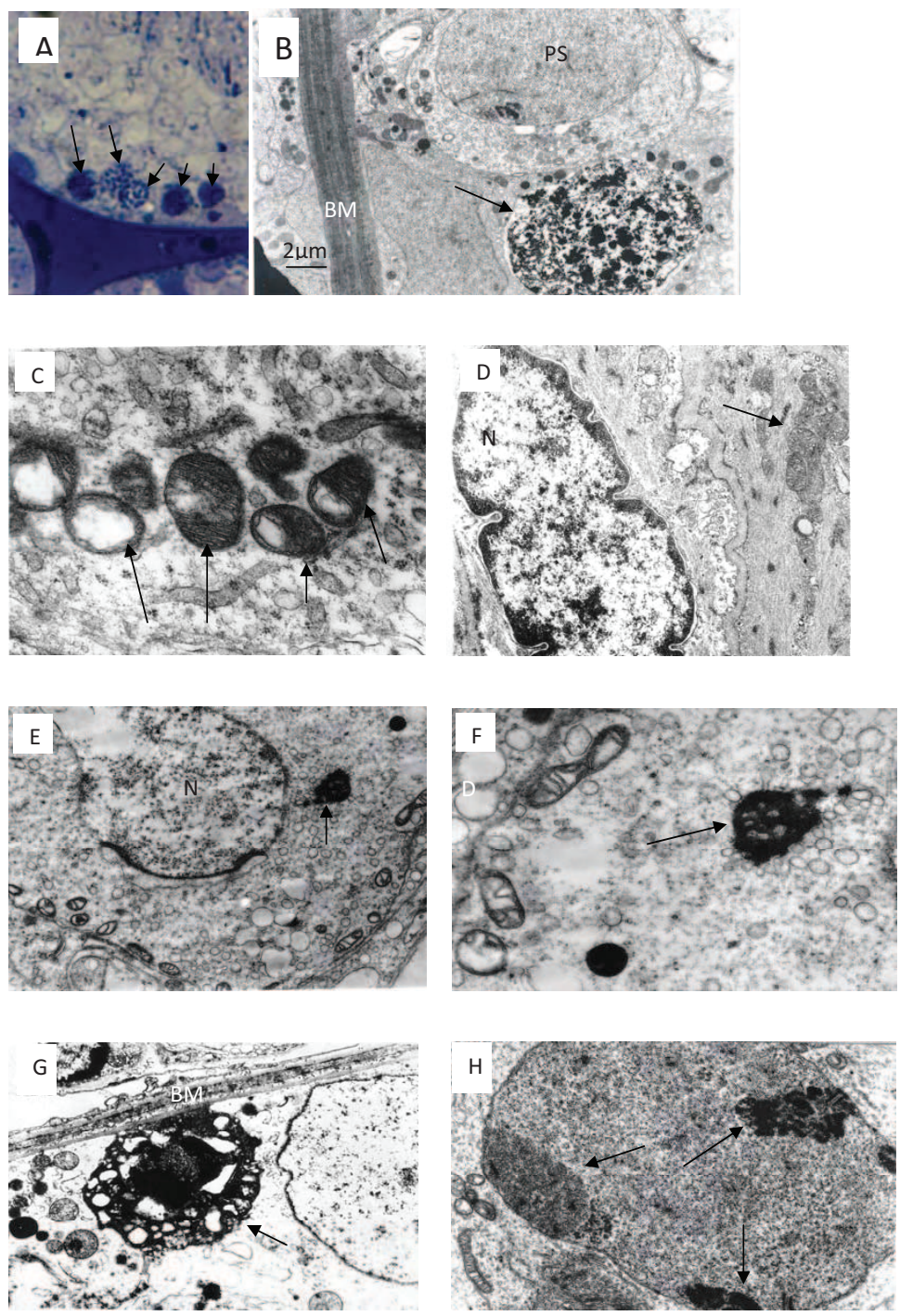

Fig. 2. Analyses of testis cross-sections from experimental group shows spermatogenic cell apoptosis $(\times 400)$ : The representatives TEM semithin (A) and TEM ultrathin (B) sections demonstrate an increase in germ cell apoptosis (arrows) in sections from experimental rats. BM Basement Membrane, PS Primary Spermatocyte. Vacuoles in the mitochondria (C) of Sertoli cells $(\rightarrow)$ in experimental group $(\times 30000)$ in comparison with normal mitochondria (D) of Sertoli cells (N: Sertoli nucleus) in control group $(\times 17000)$, dense body $(E, F)$ in the cytoplasm of spermatid cells (N: spermatid nucleolus) in experimental group $(\times 25000)$, $(\times 45000)$, degenerated $(\mathrm{G})$ cell $(\rightarrow)$ near the basement membrane $(\mathrm{BM})$ in ND-EX group $(\times 30000)$, dense clumped $(\mathrm{H})$ marginal chromatin $(\rightarrow)$ in primary spermatocytes in experimental group $(\times 35000)$. 


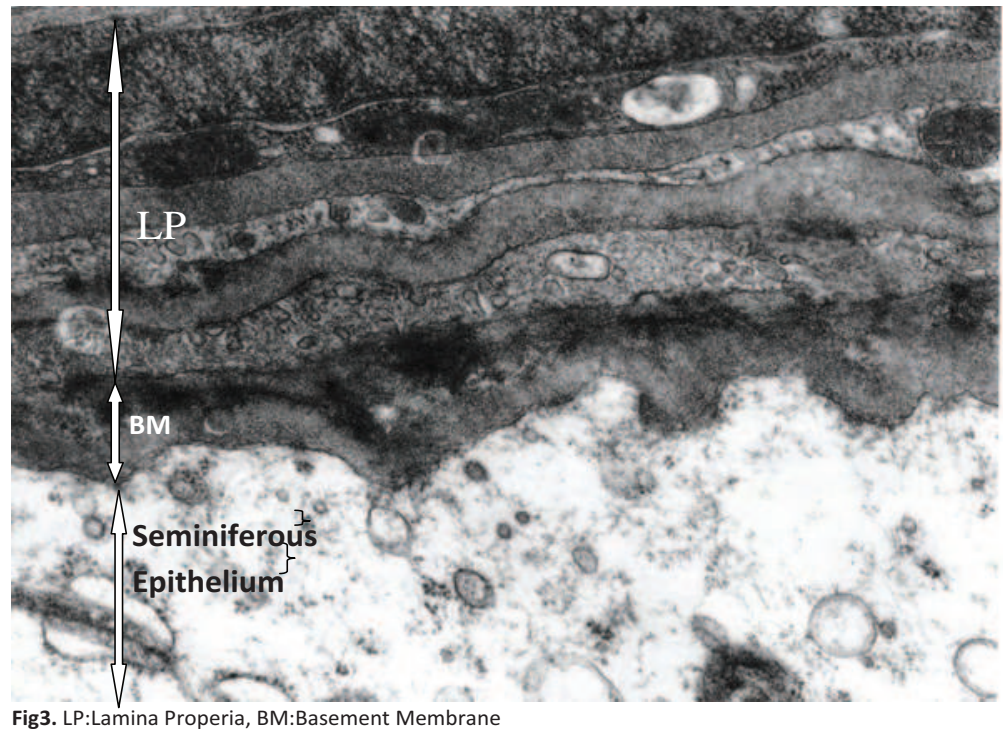

Fig. 3. LP:Lamina Properia, BM:Basement Membrane

Spermatogenic cells:

Spermatogonia

Spermatogonia are the first cells of spermatogenesis. They originate from the primordial germ cells, PGC, of epiblast layer of embryo in the 8th days of feotal development and then appear in the 4th week of development in the endodermal walls of the yolk sac and migrate to the primordium of the testis, where they finally in the puberty differentiate into spermatogonia. They are always in contact with the basal lamina of the tubule. Two types of spermatogonia can be distinguished in the human seminiferous epithelium: Type A spermatogonia have a rounded nucleus with very fine chromatin grains and one or two nucleoli. They are stem cells which divide to form new generations of both type A and type B spermatogonia (fig 4).Type B spermatogonia have rounded nuclei with chromatin granules of variable size, which often attach to the nuclear membrane, and one nucleolus. Although type B spermatogonia may divide repeatedly, they do not function as stem cells and their final mitosis always results in the formation of primary spermatocytes which lie in the cell layer luminal to the spermatogonia. They appear larger than spermatogonia. They immediately enter the prophase of the first meiotic division, which is extremely prolonged (about 22 days!). A large number of primary spermatocytes are always visible in cross-sections through seminiferous tubules. Cell divisions, from the formation of primary spermatocytes and onwards, to the production of the spermatocytes, are incomplete [2]. The cells remain connected by bridges of cytoplasm (fig 4). The completion of the first meiotic division results in the formation of

Secondary spermatocytes,

which are smaller than primary spermatocytes. They rapidly enter and complete the second meiotic division and are therefore seldom seen in histological preparations. Their division results in the formation of 
Spermatids,

Which lie in the luminal part of the seminiferous epithelium, they are small (about 10 $\mu \mathrm{m}$ in diameter) with an initially very light (often eccentric) nucleus (fig 4). The chromatin condenses during the maturation of the spermatids into spermatozoa, and the nucleus becomes smaller and stains darker [2].

The terminal phase of spermatogenesis is called spermiogenesis and consists of the differentiation of the newly formed spermatids into

\section{Spermatozoa}

The mature human spermatozoon is about $60 \mu \mathrm{m}$ long and actively motile only following epididymal maturation. It is divided into head, neck and tail.

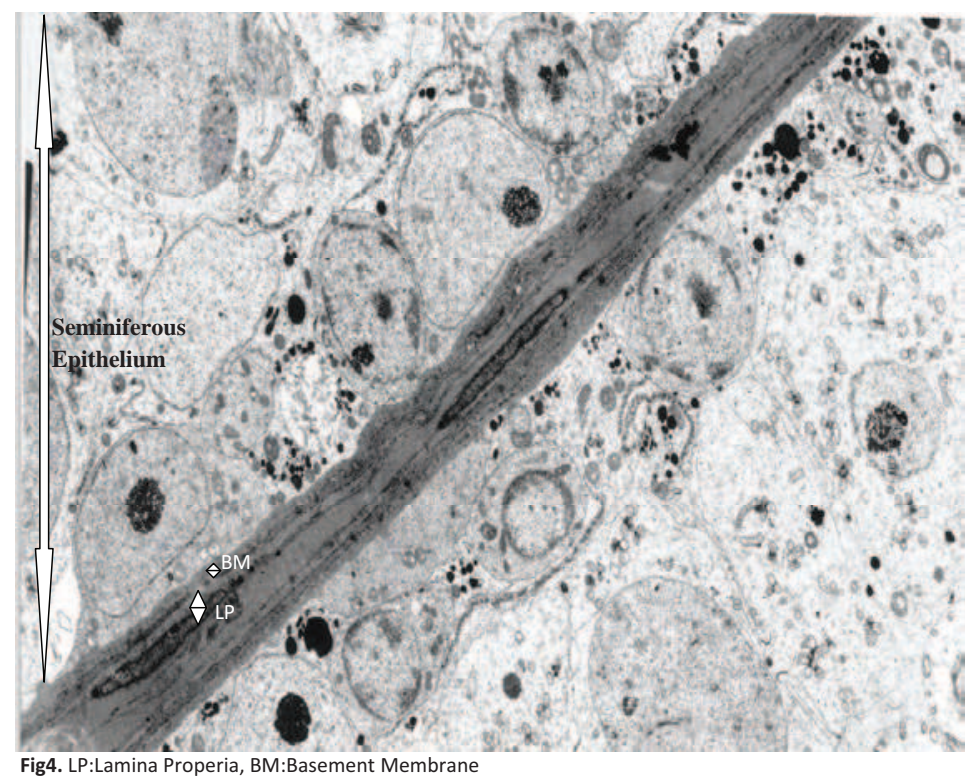

Fig. 4. LP:Lamina Properia, BM:Basement Membrane

The head (flattened, about $5 \mu \mathrm{m}$ long and $3 \mu \mathrm{m}$ wide) chiefly consists of the nucleus (greatly condensed chromatin!). The anterior $2 / 3$ of the nucleus is covered by the acrosome, which contains enzymes important in the process of fertilization. The posterior part of the nuclear membrane forms the so-called basal plate.

The neck is short (about $1 \mu \mathrm{m}$ ) and attached to the basal plate. A transversely oriented centriole is located immediately behind the basal plate. The neck also contains nine segmented columns of fibrous material, which continue as the outer dense fibers into the tail.

The tail is further divided into a middle piece, a principal piece and an end piece. The axoneme (the generic name for the arrangement of microtubules in all cilia) begins in the middle piece. It is surrounded by nine outer dense fibers, which are not found in other cilia. In the middle piece (about $5 \mu \mathrm{m}$ long), the axonema and dense fibers are surrounded by a sheath of mitochondria. The middle piece is terminated by a dense ring, the annulus. The 
principal piece is about $45 \mu \mathrm{m}$ long. It contains a fibrous sheath, which consists of dorsal and ventral longitudinal columns interconnected by regularly spaced circumferential hoops. The fibrous sheath and the dense fibers do not extend to the tip of the tail. Along the last part (5 $\mu \mathrm{m})$ of the tail, called the end piece, the axoneme is only surrounded by a small amount of cytoplasm and the plasma membrane.

It takes about 48 days from the time cells enter meiosis until morphologically mature spermatozoa are formed. Depending on the length of reproduction of spermatogonia (which is not precisely determined) it takes approximately 64 days to complete spermatogenesis.

Spermatogenesis is regulated by follicle stimulating hormone (FSH), which in males stimulates the spermatogenic epithelium, and luteinizing-hormone (LH), which in males stimulates testosterone production by Leydig cells in the interstitial tissue.

Sertoli cells

are far less numerous than the spermatogenic cells and are evenly distributed between them. Their shape is highly irregular - columnar is the best approximation. Sertoli cells extend from the basement membrane to the luminal surface of the seminiferous epithelium. Processes of the Sertoli cells extend in between the spermatogenic cells (cell limits are therefore not clearly visible in the light microscope [LM]). The nucleus of Sertoli cells is ovoid or angular, large and lightly stained and often contains a large nucleolus. The long axis of the nucleus is oriented perpendicular to wall of the tubule [2]. A fold in the nuclear membrane is characteristic for Sertoli cells but not always visible in the LM (well ... actually ... it's not that difficult to find, but not that easy either ....). Lateral processes of Sertoli cells are interconnected by tight junctions, which are likely to be the structural basis for the blood-testis barrier. Spermatogonia and primary spermatocytes are located in the basal compartment; other cellular stages of spermatogenesis are located in the adluminal compartment. Tight junctions may temporarily open to permit the passage of spermatogenic cells from the basal into the adluminal compartment. Sertoli cells provide mechanical and nutritive support for the spermatogenic cells. Sertoli cells also secrete two hormones - inhibin and activin - which provide negative and positive feedback on FSH secretion from the pituitary, respectively.

Interstitial tissue

Leydig cells $(15-20 \mu \mathrm{m})$, located in the interstitial tissue between the convoluted seminiferous tubules, constitute the endocrine component of the testis. They synthesis and secrete testosterone. Leydig cells occur in clusters, which are variable in size and richly supplied by capillaries. The cytoplasm is strongly acidophilic and finely granular. The nucleus is large, round and often located eccentric in the cell [2].

\section{Fine structure of seminiferous tubule (ST) wall}

The wall of seminiferous tubule (ST) has formed of two distinct concentrical layers: basal membrane (BM) and Lamina Propria (LP) [3]. However, some authors consider that BM is a component of the LP, being its most inner layer, in apposition with the seminal epithelium $[4,5]$. The BM is in contact with the seminiferous epithelium and contains laminin and collagen type I and IV, synthesized by Sertoli cells [5]. The LP consists of three concentric zones [6]. The middle and external ones have a total of three to seven layers of oblonged flattened secreting peritubular cells [7]. The inner zone (lamina interna) is adjacent to the $\mathrm{BM}$, containing large amounts of collagen with lamellar disposition [6]. The middle zone 
(myoid layer) consists of the first three to five incomplete layers of modified smooth muscle cells called myoid cells. These cells reside in the extracellular matrix among the fibrillary lamellar structures which, in the normal testis, are made of both collagen and laminin $[3,4$, $5,8,9]$. Myoid cells contain numerous actin, myosin and desmin filaments [10, 11]. In contrast to tubules, which underwent sclerosis, they show an intense positive reaction for actin and desmin but only focal positive reaction for vimentin [12,13]. The outer zone consists of the last two cell layers made of fibroblasts and fibrocytes containing characteristic collagen, elastin and vimentin cytoskeletal filaments [6, 11, 14]. Landon and Pryor (1981) found values over 5-7 $\mu \mathrm{m}$ within a narrow variation interval. On the other hand, Trainer (1997), found that the thickness of the two layers varied between 0.3 and $6 \mu \mathrm{m}$. Moreover, the thickening of the LP with age is considered to be rather relative as it depends on the ST decrease in length and diameter and represents the result of the reduction in volume of the seminiferous epithelium (fig3, 5) [15-19].

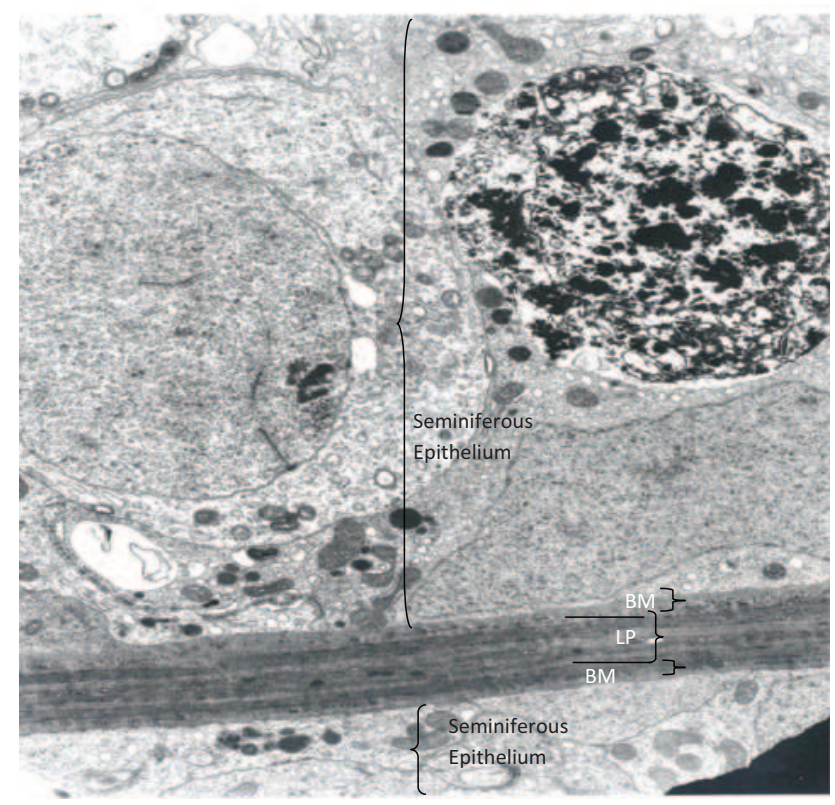

Fig. 5. LP:Lamina Propria, BM:Basement Membrane

\subsection{Evaluation of the tubular basement membrane}

For evaluation of the tubular basement membrane, we used OT POP et al pattern [49]. The dimensions of the basement membrane were evaluated on TEM samples. For each case, 10 tubules were randomly selected and photographed using the same magnification [49].

The algorithm for evaluating the basement membrane thickness was as follows:

For each tubule, five random measurements were performed and were assigned $g 1 \mathrm{CIV}, g 2$ $C I V, \ldots, g 5 \mathrm{CIV}$.

The mean thickness/tubule was calculated using the formula: 


$$
\frac{(g 1 C I V+g 2 C I V+g 3 C I V+g 4 C I V+g 5 C I V)}{5}
$$

and the values were assigned the following symbols: G1 CIV, .., G10 CIV.

The mean thickness per case was calculated using the formula:

$$
(G 1 C I V+G 2 C I V+\ldots+G 30 C I V)
$$

10

and the values were assigned the following symbols for each case: GM1 CIV, ..., GMn CIV, " $n$ " being the number of the last case from each age group.

The mean thickness for each age group was calculated using the formula:

$$
\frac{(G M 1 C I V+G M 2 C I V+\ldots+G M n C I V)}{n}
$$

And the values were assigned the following symbols:

GM 01 CIV, ..., GM07 CIV.

\subsection{Evaluation of the lamina propria thickness}

The evaluation of the lamina propria thickness was performed on the sets of serial sections:

for each case, 10 tubes were randomly selected and photographed using the same magnification of the microscope [49].

The algorithm for evaluating the lamina propria thickness was as follows: For each tubule, five random measurements were performed and were assigned $g 1, g 2, \ldots, g 5$. The mean thickness/tubule was calculated using the same formula:

$$
\frac{(g 1+g 2+g 3+g 4+g 5)}{5}
$$

And the values were assigned the following symbols: G1, G2, G3, ..., G10.

The mean thickness per case was calculated using the formula:

$$
\frac{(G 1+G 2+G 3+\ldots+G 10)}{10}
$$

And the values were assigned the following symbols for each case: GM1, GM2, .., GMn, " $n$ " being the number of the last case from each age group. The mean thickness for each age group was calculated using the formula:

$$
\frac{(G M 1+G M 2+\ldots+G M n)}{n}
$$

And the values were assigned the following symbols: GM 01, GM 02, ..., GM07. 


\section{Evaluation of ultrastructure of seminiferous tubule epithelium}

To distinguish different testicular cell types, the following ultrastructural morphological characteristics were used. Spermatogonia are located on the basal lamina of the seminiferous tubules [2]. Type A spermatogonia were identified as cells with an ovoid nucleus with the nucleoli close to the nuclear membrane. The electron-dense cytoplasm contained a small Golgi apparatus, few mitochondria and many free ribosomes. Type B spermatogonia were identified by having a more rounded nucleus and heavily stained chromatin masses attached to the nuclear membrane or to the nucleoli, located at the centre of the nucleus. Sertoli cells were recognized by their location on the basal laminae of the tubuli, by their extension to the lumen of the tubule, and by their large deeply indented nucleus with a homogeneous nucleoplasm and a prominent nucleolus [2]. The cytoplasm contained oval mitochondria, a small Golgi apparatus, an agranular endoplasmic reticulum, lipid droplets and primary and secondary lysosomes. The EM sections were studied in the following categories: (1) Seminiferous tubules: Basement membrane (BM); Spermatogenic series: various stages of maturation, sperm count, and sperm morphology; and Sertoli cells: number, size, and organelles; (2) Extracellular matrix $(\mathrm{ECM})$ and Leydig cells. Features of degeneration were fragmentation of the cell membrane, disorganization of the organelles, intracellular of edema, disruption of the endoplasmic reticulum (ER), and fractionation of mitochondria (fig1, 2) [2].

\begin{tabular}{|c|c|c|c|c|c|}
\hline Groups & Control rats & Sham rats & EX1 rats & EX2 rats & EX3 rats \\
\hline \multicolumn{6}{|l|}{ Seminiferous tubules } \\
\hline $\begin{array}{l}\text { 1. Basement membrane } \\
\text { thickening }\end{array}$ & 0 & 0 & 2 (Gr. 2) & 1 (Gr. 2) & $7($ Gr. 2) a \\
\hline \multicolumn{6}{|l|}{ 2. Spermatogonia } \\
\hline Decreased numbers & 0 & 0 & 1 (Gr. 1) & 1 (Gr. 1) & $5($ Gr. 2) a \\
\hline Degeneration & 0 & 0 & 2 (Gr. 1) & 1 & $3\left(\right.$ Gr. 2) ${ }^{\text {a }}$ \\
\hline Vacuolation & 0 & 0 & 1 (Gr. 1) & 0 & $3($ Gr. 2) a \\
\hline Apoptosis & 4(occasional) & 3(occasional) & $6(\text { single })^{a}$ & 3(single) & 7 (single $)^{a}$ \\
\hline \multicolumn{6}{|l|}{ 3. Spermatocytes } \\
\hline Decreased numbers & 0 & 0 & 1 (Gr. 1) & 1 (Gr. 1) & $3($ Gr. 1) a \\
\hline Degeneration & 0 & 0 & 2 (Gr. 1) a & 1 & $5($ Gr. 3) a \\
\hline Vacuolation & 0 & 0 & 1 (Gr. 1) & 0 & 1(Gr. 2) \\
\hline Apoptosis & 4 (occasional) & 3 (occasional) & 6 (clumps) $^{a}$ & 5(single) & 7 (clumps) $^{a}$ \\
\hline \multicolumn{6}{|l|}{ 4. Spermatids } \\
\hline Decreased number & 2(mild) & 2(mild) & 4(moderate) & 2(mild), & 5 (moderate) $^{\mathrm{a}}$ \\
\hline Abnormal morphology & 0 & 0 & 2(tail/head) a & 0 & $4(\text { head })^{\text {a }}$ \\
\hline \multicolumn{6}{|l|}{ 5. Sertoli cells } \\
\hline Increased cell number & 2 & 1 & 1 & 2 & 2 \\
\hline Increased cell size & 0 & 0 & $5^{a}$ & 0 & $7^{\mathrm{a}}$ \\
\hline Increased lipid droplets & 2 & 2 & $5^{a}$ & 1 & $7^{\mathrm{a}}$ \\
\hline
\end{tabular}

aWilkinson rank-sum test; $P$ value $<0.05$ statistically significant. EX: experimental group. EX1rats: injecting nandrolone decanoate $10 \mathrm{mg} / \mathrm{kg} /$ weekly for 8 weeks, EX2 rats: swimming exercise 1hour/day for 8 weeks and EX3 rats: ND + Exercise [2]

Table 1. Ultrstructural changes in testes

The vacuolar and degenerative changes were graded according to the percentage of cells involved as follows: grade $0:<1 \%$ of cells; grade $1: 1-25 \%$; grade $2: 25 \%-50 \%$; grade $3:>50 \%$ of cells affected. Apoptosis was similary graded as follows: grade 0: < 1\%; grade 1: $1-5 \%$; grade 2: $6 \%-10 \%$; grade 3: $>10 \%$ of cells. Cell numbers were graded as follows: grade 0: 
normal; grade \pm 1 : $25-50 \%$ increase or decrease; grade \pm 2 : $50-75 \%$ increase or decrease; grade \pm 3 : $>75 \%$ increase or decrease. Thickening of the BM was graded as 0 : BM thickness in control rats (taken as normal range); $1: 25 \%-50 \% ; 2: 50 \%-75 \% ; 3:>75 \%$ increase [2].

\begin{tabular}{|l|l|l|l|l|}
\hline Groups & CO & EX1 & EX2 & EX3 \\
\hline Seminiferous tubules & normal & $\begin{array}{l}\text { Diffuse, } \\
\text { 2+fractionation } \\
\begin{array}{l}\text { Basement } \\
\text { thembrane } \\
\text { thickening }\end{array}\end{array}$ & $\begin{array}{l}\text { Mild, focal, } \\
\text { 1+Fractionation }\end{array}$ & Diffuse, 2+ to 3+ \\
\hline Spermatogenesis & normal & $\begin{array}{l}\text { Focal Degeneration, } \\
\text { singl cell apoptosis, } \\
\text { sperm count mildly } \\
\text { decreased }\end{array}$ & $\begin{array}{l}\text { Focal Degeneration, } \\
\text { singl cell apoptosis, } \\
\text { sperm count mildly } \\
\text { decreased }\end{array}$ & $\begin{array}{l}\text { Marked degeneration, } \\
\text { Clumped apoptosis } \\
\text { Cells, All counts } \\
\text { reduced }\end{array}$ \\
\hline Sertoli cells & normal & $\begin{array}{l}\text { Increased size } \\
\text { Increased lipid } \\
\text { droplets (LD) }\end{array}$ & $\begin{array}{l}\text { Mild increase in } \\
\text { size, Mild increased } \\
\text { LD }\end{array}$ & $\begin{array}{l}\text { Incresed size } \\
\text { Increased LD }\end{array}$ \\
\hline
\end{tabular}

EX1: injecting nandrolone decanoate $10 \mathrm{mg} / \mathrm{kg} /$ weekly for 8 weeks, EX2: swimming exercise 1hour/day for 8 weeks and EX3: ND + Exercise [2]

Table 2. Changes observed in rat testes by transmission electron microscopy

\section{The ultrastrucure of Leydig cells}

In 2002 Redins CA et al measured diameters D1 and D2 from 20 nuclei with prominent nucleoli per animal. They used millimeter-ruled transparent plastic scale, which was placed on the photographs, twenty photographs per group with a same magnification $(\times 2500)$ [48]. Therefore, they used the formula $\mathrm{R}=\sqrt{\mathrm{D} 1} \times \mathrm{D} 2$. Researchers can use the geometric formula of the sphere's volume ( $\mathrm{Nvol}=164 / 3 \Pi \mathrm{R} 3$ ) for determining the nuclear volume (Nvol). Incident point counting methods is useful for counting the fractional volumes of nuclei and cytoplasm of Leydig cells [20]. In this method 414 computerized points placed on photographs, twenty photographs per animal with a same magnification $(\times 2500)$. These points randomly distributed on a net-like transparent test overlay. According to Bassi et al. (1992) and Ferreira et al. (1994) calculated the ratio between cytoplasm and nucleus (FCvol/FNvol) and the cytoplasmic volume (Cvol) of the cells $(\mathrm{Cvol}=\mathrm{Nvol} \times$ FCvol/FNvol) [21, 22]. Incident point counting methods was used for counting the cytoplasmic organells of Leydig cell as described for counting Leydig cells fractional nuclear volumes and cytoplasm. Ten $18 \times 24 \mathrm{~cm}$ photographs at a same magnification $(\times 12500)$ were examined per animal.

\section{Pathological changes of testes ultrastructure}

Some studies show a remarkable decrease in the number and size of the Leydig cells and depletion of intact cells in the experimental animals. Feinberg et al. (1997) found pyknotic and severe depletion of Leydig cells following treatment by anabolic androgenic steroids [23]. Close relationship between Leydig cells and blood vessels suggests that these cells are at high risk of exogenous toxicants and multivacuolated Leydig cells are probably a form of cell involution. Leydig cells are known to have receptors for LH that stimulates these cells to produce testosterone. Both $\mathrm{LH}$ and testosterone are responsible for normal spermatogenesis in male rats [24]. Therefore, depletion of LH receptors and decreases in peripheral LH by exogenous testosterone administration result in the reduction of testosterone secretion [25]. 
Some results suggest a reduction of synthetic activity in Leydig cells in some animals. The fractional volumes of $0.6 \%$ and $0.3 \%$ for the rough endoplasmic reticulum (RER) and Golgi complex, respectively, observed in mouse Leydig cells and reported by Mori et al.(1982), were somewhat lower than those in the experimental groups [26]. According to Palade (1975) the RER and the Golgi complex are played a role in synthesis of secretory proteins for export from the cell [27]. The Golgi complex of Leydig cells participates in the secretory pathway of glycoproteins [28]. Based on some reports, that protein synthesis may be diminished in Leydig cells of animal treated with some drugs or toxicants (fig1, 2).

An important role of basement membrane is maintaining the integrity of tissues [29]. It can stable the structure of tissue and send signals to cell [30]. Therefore, alteration of basement membrane structure can impair the severe function of testis [29]. Several proteins including laminin, type IV collagen, various heparin sulfate proteoglycans and ectatin/nidogen is collected in the basement membrane [31]. Type IV collagen is a major constituent of basement membrane which is secreted by Sertoli cells and myofibroblasts [32] and it has been localized in the inner and the outer extracellular matrix (ECM) layers of the basement membrane of seminiferous tubules [30].

Some reports have showed that some exogenous stimulants may induce myoid cells to produce more collagen and ECM that are responsible for basal lamina thickness [33]. Therefore, it may increase thickness of basement membrane and change its appearance to irregular wavy multilaminar shape (Fig 3,5).

The essential interactions for spermatogenesis are thought to be between Sertoli cells, myoid cells, Leydig cells, and germ cells. These cells must interact together by ECM of the basement membrane.

Many reports have showed that overexpression of type IV collagen correlates with thickened basement membrane and it is related to spermatogenic dysfunction in mammals $[31,33,34]$. Some studies demonstrate an increase in size of the basement membrane, others do not indicate significant changes in senescence [36-40].

Different studies that regarding testicular parenchyma, rarely mentioned changes of LP and include only general qualitative assessments. Thus, the gradual thickening of the lamina propria is parallel to tubular involution [16, 17]. Moreover, it is considered that LP thickening depending on the length and diameter decrease of the seminiferous tubules, and being the result of the disproportionate reduction in the volume of the seminiferous epithelium [16-18, 40].

Whitin the testicular epithelium observed two major changes in the Sertoli cells and in their vicinity were noticed. One was the presence of cytoplasm vacuolization, vesicular-like crista of the mitochondria, numerous lipid droplets and lysosome and phagolysosome in Sertoli cells of experimental rats. These are in agreement with the reports showing that exogenous stimulants may cause progressive apoptosis of the Sertoli cells, which affect spermatogenesis and sperm parameters [41]. The second major change was the empty vacuolar spaces between Sertoli cells that are regarded to be the place where spermatogonia and spermatocytes should be located.

In addition, the results of some studies showed that apoptosis occurred in all germ line cells especially in spermatogonia and spermatocyte. The presence of apoptotic germ cells is supported by Blanco et al. (2002) finding that has described apoptosis in hamster testis following treatment with anabolic androgenic steroids [42]. Spermatogenesis is a complex 
and dynamic process that results in the continual production of spermatozoa in mammals. The Sertoli cells are largely responsible for orchestrating the germ cells through sequential phases of mitosis, meiosis, and differentiation. The Sertoli cells accomplish this task by providing hormonal, nutritional, and physical support. Apoptosis of germ cells that occurs in the testicular epithelium serves as a mechanism to reduce the germ cell population to the level that the Sertoli cells can support. Some drugs and toxicants injure or disrupt the function of Sertoli cells and can effectively reduce their supportive role, resulting in an increase in the elimination of the germ cell numbers via apoptosis [43]. Also it has been described that apoptosis in the germ cells is related to the Fas signaling system that is activated by exogenous toxicants [43]. Observation of detached germ cells, amorphous head sperm, and mislocation of spermatid and spermatozoa to positions that are closely related to the basement membrane may be due to the rapid disruption of Sertoli-germ cell interaction. This physical interaction ultimately leads to the sloughing of the germ cells from the seminiferous epithelium [43]. It seems that the spermatogenesis cycle is reduced by the presence of high levels of androgens. On the other side, some researchers believed that some toxicants can result in an enhanced production of reactive oxygen species (ROS) in cells/tissues and exert oxidative stress (OS), which, in turn, increases the rates of cellular damage [44]. Pey et al. (2003) showed that prolonged stanozolol treatment as an AAS can cause an oxidative stress situation in rat liver [45]. Therefore, it seems logical that the physical/chemical-induced oxidative stress may affect the testicular antioxidant system and lipid peroxidation [46]. OS has been shown to be a major cause of male infertility; a large proportion of infertile men have elevated levels of seminal ROS. Several forms of sperm DNA damage are caused by ROS, e.g. chromatin cross-linking, chromosome deletion and DNA strand breaks (Apoptosis). Under physiological conditions, apoptosis maintains the number of germ cells within the supportive capacity of Sertoli cells. However, disturbances in this pathway can interrupt the spermatogenic cascade. High levels of apoptosis were detected at spermatogenic stages where major developmental blocks occur, and frequencies of DNA damage were higher in less mature germ cells [47] (Figs 2 and table 1,2).

\section{References}

[1] Shokri S, Aitken RJ, Abdolvahhabi M, Abolhasani F, Mohammad Ghasemi F et al. Exercise and supraphysiological dose of nandrolone deconoate increase apoptosis in spermatogenic cells. Basic Clinic. Pharmacol. Toxicol., 2010, 106:324-330.

[2] Naraghi MA, Abolhasani F, Kashani I, Anarkooli IJ, Hemadi M, Azami A et al. The effects of swimming exercise and supraphysiological dose of nandrolone decanoate on the testis in adult male rats: A transmission electron microscope study. Folia Morphol., 2010, 69(3):138-146.

[3] Trainer TD. Testis and excretory duct system. In: Sternerg SS (ed), Histology for pathologists, 2nd edition, Lippincott-Raven Publishers, Philadelphia, 1997:1019-1035.

[4] Gulkesen KH, Erdogru T, Sargin CF, Karpuzoglu G. Expression of extracellular matrix proteins and vimentin in testes of azoospermic man: an immunohistochemical and morphometric study. Asian J Androl., 2002, 4(1):55-60.

[5] Nistal M, Paniagua R. Non-neoplastic diseases of the testis. In: Bostwick DG, Eble JN (eds), Urologic surgical pathology, Mosby, St. Louis, 1997:458-544.

[6] Hermo L, Lalli M, Clermont Y. Arrangement of connective tissue components in the walls of seminiferous tubules of man and monkey. Am. J. Anat., 1977, 148(4):433-445.

[7] Christl HW. The lamina propria of vertebrate seminiferous tubules: a comparative light and electron microscopic investigation. Andrologia, 1990, 22(1):85-94. 
[8] Bustos-Obregon E. Ultrastructure and function of the lamina propria of mammalian seminiferous tubules. Andrologia, 1976, 8(3):179-185.

[9] Bustos-Obregon E, Holstein AF. On ultrastructural patterns of the lamina propria of human seminiferous tubules. Z. Zellforsch Mikrosk Anat., 1973, 141(3):413-425.

[10] Ross MH, Long IR. Contractile cells in human seminiferous tubules, Science, 1966, 153(741):1271-1273.

[11] Virtanen I, Kallajoki M, Narvanen O, Paranko J, Thornell LE, Mietinen M, Lehto VP. Peritubular myoid cells of human and rat testis are smooth muscle cells that contain desmin-type intermediate filaments. Anat. Rec.,1986, 215(1):10-20.

[12] Martin R, Santamaria L, Nistal M, Fraile B, Paniagua R. The peritubular myofibroblasts in the testes from normal men and men with Klinefelter's syndrome. A quantitative, ultrastructural, and immunohistochemical study. J. Pathol., 1992, 168(1):59-66.

[13] Santamaria L, Martin R, Nistal M, Paniagua R. The peritubular myoid cells in the testes from men with varicocele: an ultrastructural, immunohistochemical and quantitative study. Histopathology, 1992, 21(5):423-433.

[14] Dekrester DM, Kerr JB, Paulsen CA. The peritubular tissue in the normal and pathological human testis. An ultrastructural study. Biol Reprod, 1975, 12(3):317-324.

[15] Landon GV, Pryor JP. The blood-testis barrier in men of diverse fertility status: an ultrastructural study. Virchows Arch. A Pathol. Anat. Histol., 1981, 392(3):355-364.

[16] Johnson L. Spermatogenesis and aging in the human. J. Androl., 1986, 7(6):331-354.

[17] Paniagua R, Nistal M, Amat P, Rodriguez MC, Martin A. Seminiferous tubule involution in elderly men. Biol. Reprod., 1987, 36(4):939-947.

[18] Johnson L, Petty CS, Neaves WB. Age-related variations in seminiferous tubules in men. A stereologic evaluation, J Androl, 1986, 7(5):316-22.

[19] Johnson L, Abdo JG, Petty CS, Neaves WB. Effect of age on the composition of the seminiferous tubular boundary tissue and on the volume of each component in humans, Fertil Steril, 1988, 49(6):1045-1050.

[20] Bozzola JJ. \& Russel LD. Quantitative Electron Microscopy. In: Principles and techniques for biologists. Jones and Bartlett Publishers, Boston, 1992, 278- 304.

[21] Bassi WE, Hernandes R, Stipp ACM, Taga R. Avaliação morfométrica das dimensões do sistema de ductos estriados de glândulas parótidas do rato. Rev. Brasil. Ciên. Morfol., 1992, 9(1): 15-19.

[22] Ferreira RR, de assis GF, Taga R. Estudo morfométrico da evolução do volume nuclear e citoplasmático e da relação citoplasma/núcleo de células acinosas de glândulas parótidas do rato durante a vida pós-natal. Rev. Brasil. Ciên. Morfol., 1994, 11(2): 1142-1148.

[23] Feinberg MJ, Lumia AR, McGinnis MY. The effect of anabolic-androgenic steroids on sexual behavior and reproductive tissues in male rats. Physiol. Behav. 1997, 62 (1), 23-30.

[24] Zirkin BR. Spermatogenesis: its regulation by testosterone and FSH, Semin. Cell Dev. Biol., 1998, 9(4), 417-21.

[25] Ichihara I, Kawamura H, Nakano T, Pelliniemi LJ. Ultrastructural, morphometric, and hormonal analysis of the effects of testosterone treatment on Leydig cells and other interstitial cells in young adult rats. Ann. Anat., 2001, 183(5), 413-26.

[26] Mori H, Shimuzu D., Fukunishi Y, Christensen AK. Morphometric analysis of testicular Leydig cells in normal adult mice. Anat. Rec., 1982, 204: 333-339.

[27] Palade G. Intracellular aspects of the process of protein synthesis. Science, 1975, 189: 347-358.

[28] Lalli MF, Clermont Y. Leydig cells and their role in the synthesis and secretion of glycoproteins. Anat. Rec., 1975, 181: 403-404.

[29] Richardson LL, Kleinman HK, Dym M. Altered basement membrane synthesis in the testis after tissue injury. J. Androl., 1998, 19(2):145-55. 
[30] Martin GR, Timpl R. Laminin and other basement membrane components. Annu. Rev. Cell Biol., 1987, 3: 57-85.

[31] Dobashi M, Fujisawa M, Naito I, Yamazaki T, Okada H, Kamidono S. Distribution of type IV collagen subtypes in human testes and their association with spermatogenesis. Fertil. Steril. , 2003, 80(2):755-60.

[32] Skinner MK,Tung PS, Fritz IB. Cooperativity between sertoli cells and testicular peritubular cells in the production and deposition of extracellular matrix components. J. Cell Biol., 1985, 100 (6): 1941-47.

[33] Santoro G, Romeo C, Impellizzeri P, Arco A, Rizzo G, Gentile C. A morphometric and ultrastructural study of the changes in the lamina propria in adolescents with varicocele. BJU. Int., 1999, 83 (7):828-32.

[34] Häger M, Gawlik K, Nyström A, Sasaki T, Durbeej M. Laminin \{alpha\}1 chain corrects male infertility caused by absence of laminin \{alpha\}2 chain. Am. J. Pathol., 2005, 167(3):823-33.

[35] Bergman RA, Afifi AK, Heidger PM JR. Atlas of microscopic anatomy. Section 14: Male reproductive system. The Virtual Hospital University of Iowa College of Medicine, 1999.

[36] Sasano N, Ichijo S. Vascular patterns of the human testis with special reference to its senile changes. Tohoku J. Exp. Med., 1969, 99(3):269-280.

[37] Johnson L, Petty CS, Neaves WB. Influence of age on sperm production and testicular weights in men. J Reprod Fertil, 1984, 70(1):211-218.

[38] Neaves WB, Johnson L, Porter JC, Papker CR JR, Petty CS. Leydig cell numbers, daily sperm production, and serum gonadotropin levels in aging men. J. Clin. Endocrinol. Metab., 1984, 59(4):756-763.

[39] Meacham RB, Murray MJ. Reproductive function in the aging male. Urol. Clin. North. Am., 1994, 21(3):549-556.

[40] Plas E, Berger P, Hermann M, Pfluger H. Effects of aging on male fertility? Exp. Gerontol., 2000, 35(5):543-551.

[41] Gopalkrishnan K, Gill-Sharma MK, Balasinor N, Padwal V, D'Souza S, Parte P et al. Tamoxifen-induced light and electron microscopic changes in the rat testicular morphology and serum hormonal profile of reproductive hormones. Contraception, 1998, 57(4):261-69.

[42] Blanco A, Flores-Acuna F, Roldan-villalobos R, monterde JG. Testicular damage from anabolic treatments with the beta(2)-adrenergic agonist clenbuterol in pigs: a light and electron microscope study. Vet. J., 2002, 163(3):292-98.

[43] Richburg JH. The relevance of spontaneous- and chemically-induced alterations in testicular germ cell apoptosis to toxicology. Toxicol. Lett., 2000, 15(112-113):9-86.

[44] Davies KJ, Quintanilha AT, Brooks GA, Packer L. Free radicals and tissue damage produced by exercise. Biochem. Biophys. Res. Commun., 1982, 107(4):1198-205.

[45] Pey A, Saborido A, Blázquez I, Delgado J, Megías A. Effects of prolonged stanozolol treatment on antioxidant enzyme activities, oxidative stress markers, and heat shock protein HSP72 levels in rat liver. J. Steroid Biochem. Mol. Biol., 2003, 87(4-5):269-77.

[46] Husain K, Somani SM. Interaction of exercise training and chronic ethanol ingestion on testicular antioxidant system in rat. J. Appl. Toxicol., 1998, 18(6):421-29.

[47] Tesarik J, Greco E, Cohen-Bacrie P, Mendoza C. Germ cell apoptosis in men with complete and incomplete spermiogenesis failure. Mol. Hum. Reprod. 1998, 4(8):757-62.

[48] Redins CA, Redins GM and Novaes JC. The effects of treatment with melatonin on the ultrastructure of mouce leydig cells: a quantitative study. Braz. J. Biol. 2002, 62(3):517-523.

[49] Pop OT, Cotoi CG, Pleşea IE, Gherghiceanu M, Enache SD, Mandache E, Hortopan G, Pleşea RM. Histological and ultrastructural analysis of the seminiferous tubule wall in ageing testis. Rom J Morphol Embryol. 2011, 52(1 Suppl):241-8. 


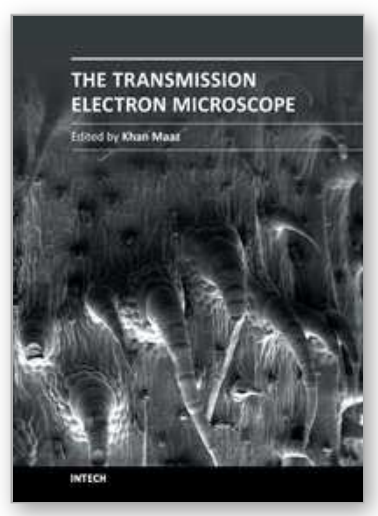

\author{
The Transmission Electron Microscope \\ Edited by Dr. Khan Maaz
}

ISBN 978-953-51-0450-6

Hard cover, 392 pages

Publisher InTech

Published online 04, April, 2012

Published in print edition April, 2012

The book "The Transmission Electron Microscope" contains a collection of research articles submitted by engineers and scientists to present an overview of different aspects of TEM from the basic mechanisms and diagnosis to the latest advancements in the field. The book presents descriptions of electron microscopy, models for improved sample sizing and handling, new methods of image projection, and experimental methodologies for nanomaterials studies. The selection of chapters focuses on transmission electron microscopy used in material characterization, with special emphasis on both the theoretical and experimental aspect of modern electron microscopy techniques. I believe that a broad range of readers, such as students, scientists and engineers will benefit from this book.

\title{
How to reference
}

In order to correctly reference this scholarly work, feel free to copy and paste the following:

Saeed Shokri, Masoud Hemadi and Robert John Aitken (2012). Transmission Electron Microscopy for the Quantitative Analysis of Testis Ultra Structure, The Transmission Electron Microscope, Dr. Khan Maaz (Ed.), ISBN: 978-953-51-0450-6, InTech, Available from: http://www.intechopen.com/books/the-transmissionelectron-microscope/transmission-electron-microscopy-for-the-quantitative-analysis-of-testis-ultra-structure

\section{INTECH}

open science | open minds

\section{InTech Europe}

University Campus STeP Ri

Slavka Krautzeka 83/A

51000 Rijeka, Croatia

Phone: +385 (51) 770447

Fax: +385 (51) 686166

www.intechopen.com

\section{InTech China}

Unit 405, Office Block, Hotel Equatorial Shanghai

No.65, Yan An Road (West), Shanghai, 200040, China

中国上海市延安西路65号上海国际贵都大饭店办公楼 405 单元

Phone: +86-21-62489820

Fax: +86-21-62489821 
(C) 2012 The Author(s). Licensee IntechOpen. This is an open access article distributed under the terms of the Creative Commons Attribution 3.0 License, which permits unrestricted use, distribution, and reproduction in any medium, provided the original work is properly cited. 